Töke, Lilla. "Virginás, Andrea, ed. 2016. Cultural Studies Approaches in the Study of Eastern European Cinema: Spaces, Bodies, Memories. Cambridge, UK: Cambridge Scholars Publishing. 291 pp. Illus.." Hungarian Cultural Studies. e-Journal of the American Hungarian Educators Association, Volume 10 (2017) DOI:

\title{
Virginás, Andrea, ed. 2016. Cultural Studies Approaches in the Study of Eastern European Cinema: Spaces, Bodies, Memories. Cambridge, UK: Cambridge Scholars Publishing. 291 pp. Illus.
}

\author{
Reviewed by Lilla Tőke*, City University of New York, LaGuardia Community College
}

In the summer of 1990, during his first visit to Warsaw, former U.S. Secretary of State Henry Kissinger greeted the local crowd saying: "I'm delighted to be here in Eastern, I mean Central Europe." To Kissinger's credit, it should be pointed out that in the early 1990s the European region he was referring to, East-Central Europe, had just undergone seismic sociocultural transformations with the 1989-1990 fall of communism in the entire Soviet bloc. Since then and in the last quarter of a century the debate over the position of this large region within and vis-à-vis Europe has become the focus of numerous scholarly debates. The present collection of articles devoted to film studies in this region, entitled Cultural Studies Approaches in the Study of Eastern European Cinema: Spaces, Bodies, Memories and edited by Andrea Virginás, evidently does not share Kissinger's geopolitical hesitation. Instead, the title of this collection firmly positions the countries it discusses in Eastern Europe although some of them, like Poland and Hungary, have for decades if not centuries considered themselves to be Central European or East-Central European. In addition, this volume also contains articles on the cinemas of such South-Eastern European countries as Serbia, Croatia, and Slovenia. The concern with the book's title is therefore symptomatic of a larger present-day aspiration, not untypical in the fields of cinema and cultural studies, to establish a coherent regional and transnational methodology for the study of postsocialist East-Central Europe.

If the title of the volume is as promising as it is problematic, the list of its contributors also seems somewhat enigmatic in that many of the names are unknown to Western European or U.S. scholars. This is due to the fact that, as the preface tells us, editor Andrea Virginás chose to showcase in this collection mostly the "early-to-mid-career generation of Eastern European film scholars" living and working in the region (viii). The volume indeed fulfills the need to provide film studies with works by researchers intimately familiar with the region and the state of cinema studies in it including the field's "interpersonal and institutional networks" (viii). Divided into three parts and with a focus on "Space," "Body," and "Memory," the volume strives to configure the contextualized relationships amongst these "well-canonized" concepts within present-day cultural studies (ix). It is unfortunate that, after promising a fresh look at today's scholarship by

\footnotetext{
*ltoke@lagcc.cuny.edu
}

(cc) $\mathrm{EY}$

ULIS D-Sonk
New articles in this journal are licensed under a Creative Commons Attribution 4.0 International License.

This journal is published by the University Library System of the University of Pittsburgh as part of its D-Scribe Digital Publishing Program and is cosponsored by the University of Pittsburgh Press 
Tőke, Lilla. "Virginás, Andrea, ed. 2016. Cultural Studies Approaches in the Study of Eastern European Cinema: Spaces, Bodies, Memories. Cambridge, UK: Cambridge Scholars Publishing. 291 pp. Illus..” Hungarian Cultural Studies. e-Journal of the American Hungarian Educators Association, Volume 10 (2017) DOI:

10.5195/ahea.2017.293

young film scholars from the region, the volume's introductory and framing article, written by Anikó Imre, is a reprint of her 2014 canonical study, "The Case for Postcolonial, Postsocialist Media Studies" (originally published in Boundary $241.1,113-134$ ), in which she applies postcolonial theory to Eastern-European postsocialist television and film. As such, Imre's article adds little to the volume's declared attempt at sounding new voices and offering innovative perspectives for the study of East-Central European cinema.

The full title of the volume's first part, "Postcolonial, Postsocialist Spaces (of the Nation)" reflects an effort to group together four articles dealing with the potential of cinematic space to construct or articulate national identity. Zsolt Györi's contribution, "Concrete Utopian: Discourses of Domestic Space in Hungarian Cinema," offers an original and illuminating interpretation of the role of prefabricated-panel housing in the Hungarian cultural imagination as reflected in Hungarian film. Györi claims that panel houses have had a structural impact on the very texture of socialist and postsocialist Hungarian society because their readymade, unified patterns "organize people's psyches, determine their notions of domestic and private life, affect communal activities and socializing patterns" (29). He goes on to construct a brief cultural history of domestic space through the cinematic representation of panel housing and interprets it as a "catalyst" for the relationship between socialist and postsocialist ideology and the self (41).

Michel Foucault's key concept of heterotopia serves as a recurring analytical term in the entire collection. In the article titled "From Heterotopias to Non-Places: The (National) Identity Reviewed through Spaces of Contemporary Slovak Cinema," Jana Dudková makes use of French anthropologist Marc Augé's theory of supermodernity to argue that in Slovak cinema the proliferation of heterotopic "non-places" such as highways, airports and shopping centers discloses a national crisis within a hyperglobalized world, wherein places she sees as "real," "authentic," and "historical" have largely disappeared (63). Following Dudková's article, the editor's own contribution to the volume is a transnational take on notions of cinematic space in Romanian and Hungarian New-Wave cinemas. "Fragile Diegetic Places and Mobile Women: Coping with Trauma in Hungarian and Romanian Films" examines the postsocialist cinemas in these two countries through a combination of gender studies and psychoanalytic film theory. Offering a highly formalistic reading of mise-en-scène instances and techniques, Virginás makes the claim that the prominence of extra- and meta-diegetic shots in both Romanian and Hungarian films "informs us about the process of building trauma narratives" (77). These narratives, which often present women's traumatized bodies in disjointed diegetic spaces, such as the hotel room in 4 luni, 3 saptamani si 2 zile [' 4 Months, 3 Weeks, and 2 Days'] (directed by Cristian Mungiu, 2007), ultimately reveal the collective traumas so typical of the socialist and postsocialist periods in these two countries.

The next chapter is also transnational in its scope. Edward Alexander's article, "The Titular Nation in (Post)Yugoslav Cinema," discusses a particular subgenre of national cinema films with the nation's name explicitly stated in their titles, e.g.: Slovenska ['Slovenian Girl'] (dir. Damjan Kozole, 2009), or Sprski Film ['A Serbian Film'] (dir. Srđan Spasojević, 2010).

Alexander claims that the filmmakers' artistic intentions to firmly (even if at times ironically) ground a sense of national identity in their films through the insertion of the country's name in the film's title is ultimately upended by the reception of these films because eventually it is the viewers who decide what and how they see through their own conceptualizations of their nations. 
Tőke, Lilla. "Virginás, Andrea, ed. 2016. Cultural Studies Approaches in the Study of Eastern European Cinema: Spaces, Bodies, Memories. Cambridge, UK: Cambridge Scholars Publishing. 291 pp. Illus..” Hungarian Cultural Studies. e-Journal of the American Hungarian Educators Association, Volume 10 (2017) DOI: 10.5195/ahea.2017.293

The second part of the book is devoted to the issue of embodiment in and through cinematic space. This part is of particular interest for scholars of Hungarian cinema and culture as three of the four articles in it deal with Hungarian films. György Kalmár's contribution titled "Apostate Bodies: Nimród Antal's Kontroll and Eastern European Identity Politics," offers an interpretation of the characters in Nimród Antal's 2003 film, Kontroll ['Control'] as metaphorical embodiments of the contradictions between national-Hungarian and European identities. National politics, Kalmár contends, are projected onto the male bodies in this film to connect "the male subjects' exclusion from power to a crisis of masculinity" (119). The author goes on to argue that the crisis in the literal and symbolic underground world of the Budapest subway featured in this film is in fact allegorical of the cultural and socio-psychological subconscious of Hungarian society as it deals with "integration and redemption" within the European Union. Kalmár also interprets the controllers' criminal behavior as symptomatic of the rampant political corruption in Hungary (124).

In her article titled "Corporeality and Otherness in the Cinematic Heterotopias of Bibliothèque Pascal," Katalin Sándor implements, like others in this volume, Foucault's concept of heterotopia in her close reading of the Hungarian film Bibliothèque Pascal (dir. Szabolcs Hajdú, 2010). While analyzing the female protagonist's surreal quest to regain custody of her daughter, which leads to the mother's entrapment in a debouched Liverpool brothel-library, Sándor focuses on the transformative effect of these liminal spaces on the female bodies occupying them. Sándor is particularly successful in describing the ways in which the female body navigates and negotiates amidst these in-between spaces. The third article on Hungarian cinema in this part is titled "Post-Bodies in Hungarian Cinema: Forgotten Bodies and Spaces in Ágnes Kocsis's Pál Adrienn” and was written by Eszter Ureczky. Like Sándor, Ureczky, too, tackles issues of gender, embodiment and heterotopia in her interpretation of Kocsis's 2010 film ['Adrienn Pal']. The film, which presents the story of a lonely and extremely obese nurse who works in a hospital terminal-ward, serves, for Ureczky, as an allegory of "awakening." The nurse's quest of finding a long-lost friend named Adrienn Pal triggers a fundamental transformation in her as on this journey she turns from an invisible non-entity into an actualized subject, "an entity continuous with itself" (183); and most importantly, she changes from a person that used to be forgotten by others into one who is able to forget others.

The focus of the third and last part of the Study of Eastern European Cinema is directed at cultural memory in postsocialist cinema. The relationships of history and memory, trauma, rememory and amnesia have been explored from multiple theoretical perspectives in groundbreaking books such as Paul Ricoeur's 2004 Memory, History, Forgetting and, in the EasternEuropean context, Svetlana Boym's 2002 The Future of Nostalgia. The articles in this part, however, do not build on the existing, rich scholarship on socialist and postsocialist trauma, memory and nostalgia studies. Instead, Elżbieta Durys in her article "'You want the truth? How do you know you won't choke on it?': The Issue of Memory in Aftermath" suggests a rather transparent connection between history, memory and Polish national identity. Durys makes the claim that the Polish film Poklosie ['Aftermath'] (dir. Władysław Pasikowski, 2012), which recounts the dramatic and ultimately tragic fate of two Polish brothers on a quest to learn and deal with their village's anti-Semitic, fascist past, serves as a forceful example of cinematic memory challenging historical narratives about the Polish nation's role in World War II. 
Tőke, Lilla. "Virginás, Andrea, ed. 2016. Cultural Studies Approaches in the Study of Eastern European Cinema: Spaces, Bodies, Memories. Cambridge, UK: Cambridge Scholars Publishing. 291 pp. Illus..” Hungarian Cultural Studies. e-Journal of the American Hungarian Educators Association, Volume 10 (2017) DOI:

10.5195/ahea.2017.293

The volume's last part also includes two highly ambitious articles that deal with Romanian New-Wave cinema. While the first attempts to point at major tendencies in recent Romanian cinema, the second criticizes it. In "Paradigms of Rememoration in Postcommunist Romanian Cinema," Claudiu Turcuș gives a broad overview and "typology of [cinematic] representations of communism" (217) to conclude that there are two dominant paradigms representing collective memories of anti-communism in postsocialist Romanian cinema. One, which characterizes Romanian films from the 1990s, shows signs of a strong "retributive, regulatory" tendency in its anti-communist tone, which becomes a central ideology in these films. The second paradigm, which appears together with the Romanian New Wave, is more self-questioning and refuses "to adopt a hard anti-communist vision" (239). By contrast to Turcuș's article Doru Pop's closing article, "Making and Breaking the New Wave Canon in Romanian Cinema," argues that Romanian New-Wave cinema is at present in a hollowed-out state since most directors are incapable of producing really new and original work and instead they are "either repeating their own recipes or mixing old and new canons" (272). But then, in direct opposition to his own contention that Romanian directors both aesthetically and ideologically "self-canonize" themselves (270), Pop concludes his article with a "final" and "personal" list of films that, according to him, make up today's Romanian New-Wave canon, thus offering up the very same canon he just attempted to deconstruct and criticize (286).

On the whole, the collection at hand is a highly eclectic snapshot of the work done by current film scholars in East-Central Europe. The scope of the articles spreads from major theoretical issues of interpretative methodology, canonization, and genre typology to very specific, close readings of individual films. Unfortunately, the quality of the contributions is somewhat uneven as some of them fall short of providing a fresh or cohesive analysis of EastCentral European film. Nevertheless, one can confidently say that there are among them a few surprisingly insightful accounts exhibiting fine perceptions of the ways in which space, memory, and the body operate in Central- and Eastern-European national cinemas. While not all of these articles are necessarily examples of "cultural studies," as a whole they are indeed successful in combining formalistic readings of spaces and their embodiments with questions of representation related to issues of the nation, gender, and the postsocialist condition. 